Potravinarstvo Slovak Journal of Food Sciences

vol. 15, 2021, p. 555-565

https://doi.org/10.5219/1629

Received: 5 May 2021. Accepted: 11 June 2021.

Available online: 28 June 2021 at www.potravinarstvo.com

(C) 2021 Potravinarstvo Slovak Journal of Food Sciences, License: CC BY 4.0

ISSN 1337-0960 (online)

\title{
THE BIOCHEMICAL CHANGES IN LEGUMES DURING HIGH-TEMPERATURE MICRONIZATION
}

\author{
Otari Sesikashvili, Elene Gamkrelidze, Nodari Mardaleishvili, Gia Dadunashvili, Shalva \\ Tsagareishvili, George Pkhakadze
}

\begin{abstract}
The article considers the change in chemical and biological characteristics in some legumes grains, under conditions of hightemperature micronization with different moisture contents during heat treatment with infrared rays. The heat treatment of grains was carried out on a laboratory apparatus with a quartz radiant infrared panel. The temperature variation in the heat treatment zone occurred due to changing the distance between the panel and the surface of grains. The grain temperature was determined using a laser thermometer, and with a timer. To determine chemical and biological characteristics, we used a special optical density metering device. We have studied: 1 . The dependence of starch content on the temperature in the changing initial moisture content. We found that after 30 seconds of high-temperature micronization of, "Tsanava" beans at a grain moisture content of $12.7 \%$, the starch content in the grain increases from $39.65 \%$ to $40.12 \%$, then gradually decreases, and at $18.3 \%$ moisture content, it increases from $38.71 \%$ to $41.2 \%$, with a moisture content of $28.6 \%$ it increases from $37.36 \%$ to $42.42 \%$. Similar processes are also observed for the beans "field red" and "white lupine“; 2 . The dependence of glucose content on the temperature in the changing initial moisture content. As the mass fraction of starch decreases, the percentage of sugar (in terms of the equivalent amount of glucose) at a moisture content of $12.7 \%$ at the initial stage increases from $1.36 \%$ to $1.46 \%$, and then the percentage of sugar increases relatively quickly to $1.64 \%$, at a moisture content of $18.3 \%$ it increases from $1.3 \%$ to $1.38 \%$, and then increases to 1.51 , with a moisture content of $28.6 \%$, it increases from $1.28 \%$ to $1.35 \%$ and then increases to 1.54 . Similar processes are also observed for the beans "field red" and "white lupine".
\end{abstract}

Keywords: bean; lupine; starch; glucose, high-temperature micronization; heat treatment.

\section{INTRODUCTION}

The bean ranks second after pea among legumes in popularity and spread. In earlier centuries, legumes such as lupine proved to be very popular in Georgia, but now it is almost forgotten. Various food products are produced from beans. The dried beans are extensively used in dietetic nutrition for the treatment of atherosclerosis and preventing heart rhythm disorders. The beans are part of the Arfazetin collection and are used in the treatment of diabetes. In folk medicine, the dried bean tincture is used in the treatment of kidney disease, rheumatism, hypertension, and diabetes (Markov, Markov and Vodenicharova, 2016).

The authors (Ntatsi et al., 2018) point out that legumes are considered to be important plant sources. They contain protein, essential minerals, carbohydrates, vitamins, and biologically active compounds, which are very important for humans and also contain phytochemicals such as phenolic acids, anthocyanins, proanthocyanidins, and flavonols (Murphy et al., 2018). These phytochemicals have been identified in different legume species (Moreno-
Valdespino et al., 2019). Bean contains about 23\% proteins, most of which are water-soluble (Recommendations for healthy, 2006); up to $55 \%$ carbohydrates (starch); small amounts of oligosaccharides, including $4.7 \%$ cellulose; up to $1.5 \%$ fatty acids; carotene; macronutrients, such as potassium (1160 mg\%), calcium (220 mg\%), phosphorus, copper, zinc; nitrogen-containing substances, including amino acids; flavonoids, organic acids, as well as B and PP group vitamins, pyridoxine, thiamine, pantothenic and ascorbic acids (Markov, Markov and Vodenicharova, 2016). Raw beans, especially red beans contain significant amounts of alkaloids that have toxic effects. To neutralize the latter, the heat treatment is used by boiling water (for less than 30 minutes) (Markov, Markov and Vodenicharova, 2016). Grain Legumes are very important for human nutrition and contain high amounts of carbohydrates that are slowly released (Afzal et al., 2020), where starch is the major carbohydrate in legumes. The share of starch is $40-50 \%$ of their total weight. In their chemical compositions, beans and 


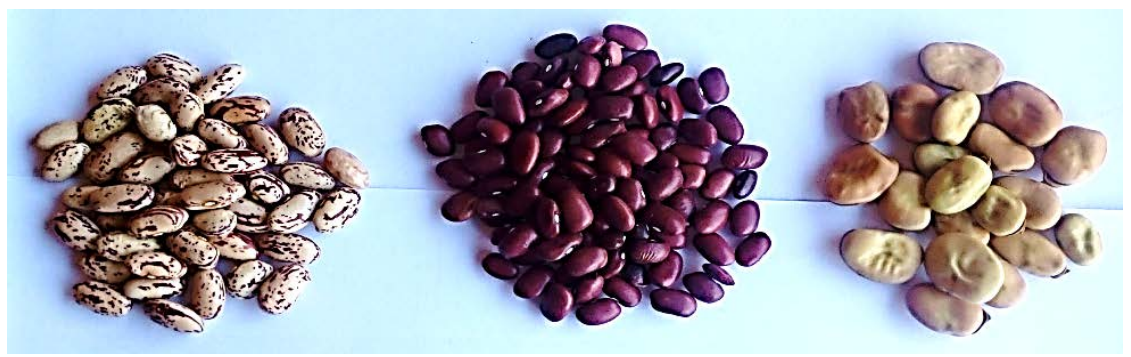

A

B

C

Figure 1 General view of the test legumes. Note: A - Beans of the „Tsanava“ variety; B - Beans of the „Field red“ variety; C - Beans „White Lupine“.

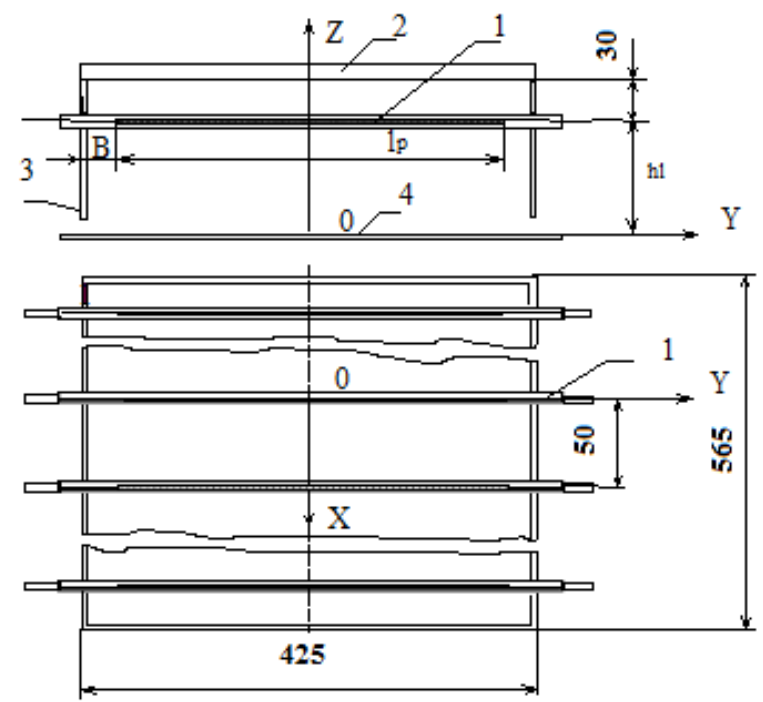

Figure 2 Diagram of the experimental-industrial block of the emitters: 1 - QP1-type infrared source; 2 - Top reflector; 3 - Side reflector; 4 - A working surface of the processing zone.

lupine are close to meat, which is well assimilated into the human body (Samchenko, 2014). In a variety of metabolic syndromes, legumes have several health benefits (Jeong et al., 2018). These crops could be valuable functional and/or medicinal food (Mainali et al., 2014).

During thermal treatment of grain with infrared rays, chemical processes are activated, however, infrared rays do not appear to have a direct impact on biological objects, as in the case of ultraviolet rays, at least, there are few or no results achieved in this area available in the existing literature. Various biochemical processes occur in the grain resulting from thermal action. At this time, there can take place protein denaturation, starch dextrinization, inactivation of biologically active substances and microorganisms, and so on.

The starch contained in legumes swells up in the presence of moisture at a temperature of $50-90{ }^{\circ} \mathrm{C}$ the swollen granules lose the double refraction ability, crystallites are melting and the polymers are opening. When the temperature is about $65{ }^{\circ} \mathrm{C}$, under conditions of excess moisture, after the completion of the first stage of pregelatinization of starch, starch can retain about $85 \%$ of water (Khosny, 2006). During further heating, the pregelatinization process continues (Fast and Kolduell, 2007).
Individual components and microflora of a heterogeneous structure of legume grains have different absorption coefficients, and therefore, in processing them with infrared rays, they have different local temperatures, especially in the non-stationary period, which indicates the singularity of radiation heating (Fast and Kolduell, 2007).

Based on the review of the literature and the analysis of the problem to be solved, we developed the direction of the research and defined the purpose of the research.

The research described in this article aims to study the dependence of the starch and glucose content on temperature during high-temperature micronization, with a change in the initial hygroscopic humidity. Based on the obtained experimental data, the compilation of a mathematical model will allow us to investigate the process of other legumes.

\section{Scientific Hypothesis}

In the process of high-temperature micronization, in a short time, under the high heat impact, carbohydrates in the legume grains are partially inactivated and split into simple carbohydrates with the formation of dextrins, biologically active substances are inactivated, and proteins are partially denatured. Activation of this process in the grain, by creating proper optimal conditions, will eventually lead to an improvement in the nutritional value of legumes. 


\section{MATERIAL AND METHODOLOGY}

The research covered the varieties of bean such as „Tsanava“ variety (Gori, Gori Region, Georgia), „field red“ bean (Tskhaltubo, Tskhaltubo Region, Georgia), and the socalled „white lupine“ (Khoni, Khoni Region, Georgia), Figure 1.

The heating of legume grain was carried out on the laboratory equipment with the quartz halogen linear infrared emitters panel type QP1 (Elcer, Odesa, Ukraine). The diagram of this equipment is shown in Figure 2.

The irradiance on the working surface in the processing zone was determined through a calculation using a specially developed program. Variation by height installation of IR panel above the monolayer of grain product and the type of pallet allowed changing independently, under a limited range, the irradiance and ambient temperature in the treatment zone.

The authors (Tóth et al., 2018) note that many factors affect the content of useful compounds in legumes, such as agrochemical processing, climatic conditions, as well as varieties and conditions of their storage.

The initial moisture content of beans was determined using an electronic digital meter of grain and seed moisture (moisture meter) VSP-100 (PAtools, Kharkiv, Ukraine). Additionally, the moisture loss during IR heating was estimated as the difference between the initial sample weight and its weight after heat treatment. The sample weight of the grain before and after heat treatment was determined using an SF-400C model (Toms, Qilin, China) electronic digital analytical balance, with a weighing accuracy of $0.01 \mathrm{~g}$. The moisture content (W) after heat treatment was calculated based on the initial moisture content $\left(\mathrm{W}_{0}\right)$ and mass loss $(\Delta \mathrm{m})$ according to the formula based on the standards GOST 13586.5 (2015) and ISO 3166 (2015)

$$
\mathrm{W}=100\left[\mathrm{~W}_{0} / 100-\Delta \mathrm{m} / \mathrm{m}_{0}\right] /\left[1-\Delta \mathrm{m} / \mathrm{m}_{0}\right]
$$

Where:

$\mathrm{W}_{0}$ - initial moisture, \%; $\mathrm{m}_{0}$ - initial sample weight, g; $\Delta \mathrm{m}$ - sample weight loss, $\mathrm{g}$.

To determine the percentage of starch in the samples, we prepared 5 samples of calibrating with different starch contents from pure starch and determined their optical density. After treatment with potassium iodide (Potassium iodide for analysis, KI, Merck, $\geq 99.5 \%$ ) and iodine solution (Crystalline iodine, $\mathrm{I}_{2}$, Merck, $\geq 99.9 \%$ ), data obtained by using the optical density metering device KFK-2 (PP ZOMZ, Zagorsk, Russia), we constructed a calibration curve at coordinates: starch content $\mathrm{mg} \cdot(10 \mathrm{~mL})^{-1}-$ optical density.

Three samples of beans and lupine for each moisture content were crushed in a laboratory grain crushing machine (Retsch, Kyiv, Ukraine) and passed through a laboratory sieve No. 08 (Retsch, Kyiv, Ukraine). The obtained bean flour in the amount of $0.5 \mathrm{~g}$ was put in a porcelain cup and crushed well, then it was placed in a flask and fill it with $300 \mathrm{~mL}$ of distilled water. The flask was placed in a water bath and the temperature of the mixture was brought up to $95{ }^{\circ} \mathrm{C}$, then it was quickly cooled with running water and the flask was filled with distilled water up to the $500 \mathrm{~mL}$ mark. The solution was filtered through a laboratory filter paper. After treatment with potassium iodide and iodine solution, we determined the optical density of solution obtained on the machine KFK-2 (PP ZOMZ, Zagorsk, Russia), and with the help of a calibrating curve, we determined the percentage of starch in the sample in a g$\mathrm{mg} \cdot(10 \mathrm{~mL})^{-1}$ solution. The analysis of the samples was repeated three times and the experiments were repeated three times. The mass content of starch in the sample was calculated by a formula based on the standards GOST 10845 (1998) and ISO 6493 (2000)

$$
\mathrm{X}_{\mathrm{s}}=\mathrm{g} \cdot 100 \cdot \mathrm{V} / \mathrm{m} \cdot 1000 \cdot 10
$$

\section{Where:}

$\mathrm{g}$ - starch content which is determined in accordance with the optical density from a calibrating curve, $\mathrm{mg} \cdot(10 \mathrm{~mL})^{-1}$; $\mathrm{V}$ - the total volume of solution, $\mathrm{mL} ; \mathrm{m}$ - the mass of the analysis sample, $\mathrm{g}$.

To determine the amount of reducing sugars in the samples, we prepared 6 samples of calibrating solution from pure glucose with different glucose contents, to which we added potassium hexacyanoferrate (III) solution (Potassium hexacyanoferrate (III), $\mathrm{K}_{3} \mathrm{Fe}(\mathrm{CN})_{6}$, Merck, $\geq 99.0 \%$ ) and then we determined their optical density using the optical density metering device KFK-2 (PP ZOMZ, Zagorsk, Russia), then according to data obtained, we constructed a calibration curve at coordinates: glucose content $\mathrm{mg}$. $(35 \mathrm{~mL})^{-1}$ - optical density.

Samples for the determination of reduced sugars were prepared as a previous experiment with three samples of beans and lupine for each moisture content. We placed in a flask $25 \mathrm{~mL}$ of potassium hexacyanoferrate (III) solution, $8 \mathrm{~mL}$ of a clear filtrate of the analysis sample, and $2 \mathrm{~mL}$ of distilled water. Then we boiled it for 1 minute and cooled it quickly with running water. Then we determined the optical density of the solution using the optical density metering device KFK-2 (PP ZOMZ, Zagorsk, Russia), and with the help of a calibrating curve, we determined the percentage of reduced sugars in the sample in a g-mg solution. The analysis of the samples was repeated three times and the experiments were repeated three times.

The percentage of reducing sugar content in the sample was calculated by a formula based on the standards GOST 29177 (2004) and ISO 3946 (1982)

$$
\mathrm{X}_{\mathrm{gl}}=\mathrm{g} \cdot 100 \cdot \mathrm{V}_{1} / \mathrm{m} \cdot \mathrm{V}_{2} \cdot 1000
$$

Where:

$\mathrm{g}$ - glucose content which is determined following the optical density from a calibrating curve, mg; $V_{1}-$ the volume of an aqueous solution of the prepared sample, $\mathrm{mL}$; $\mathrm{V}_{2}$ - the volume of an aqueous solution of the sample taken for the reaction with potassium hexacyanoferrate (III) solution, $\mathrm{mL} ; \mathrm{m}$ - the mass of the sample, $\mathrm{g}$.

The author (Samchenko, 2014) has studied the possibility of using legumes (peas, beans, and lentils) in the production 
Table 1 A comparative analysis of the chemical composition of legumes and beef.

\begin{tabular}{lcccc}
\hline \multirow{2}{*}{ Parameter } & \multicolumn{3}{c}{ Chemical composition, \% } \\
\cline { 2 - 5 } & Peas & Beans & Lentils & Beef \\
\hline Moisture content & 14.0 & 14.0 & 14.0 & 64.5 \\
\hline \multicolumn{1}{c}{ Macronutrients } & & \\
\hline Protein & 20.5 & 21.0 & 24.0 & 18.6 \\
Fat & 2.0 & 2.0 & 1.5 & 16.0 \\
Carbohydrates & 49.5 & 47.0 & 46.3 & 0.9 \\
including: & & & & \\
Starch & 44.9 & 43.8 & 43.4 & - \\
Mono- and disaccharides & 4.6 & 2.9 & 3.2 & - \\
Dietary fibers & 11.2 & 11.5 & 12.4 & - \\
\hline
\end{tabular}

of minced meat semi-finished products. A comparative analysis of the chemical composition of legumes and raw meat was carried out, the results of which are given in Table 1.

It has been shown that legumes contain significantly less water than meat, which represented their high nutritional value, and they also contain significantly less fat, i.e. are dietary products. Peas, beans, and lentils surpass meat in the percentage of protein and carbohydrates, including dietary fibers that are absent in meat, which allows for better binding and retaining moisture in the minced meat system. For the process of heat treatment with infrared rays, mathematical models of temperature and humidity change in the grain are compiled, which are described by nonlinear differential equations:

$$
\begin{gathered}
\mathrm{C} \cdot \mathrm{M} \cdot \mathrm{d}(\Delta \mathrm{T}) / \mathrm{dt}=\mathrm{S}_{1} \cdot\left\{\mathrm{K}_{\mathrm{s}} \mathrm{A} \cdot \mathrm{E}(\mathrm{t})+\mathrm{K}_{\mathrm{a}}\left[\Delta \mathrm{T}_{\mathrm{c}}(\mathrm{t})-\right.\right. \\
\left.\left.-\mathrm{K}_{\mathrm{g}} \cdot \Delta \mathrm{T}\right]-\mathrm{K}_{\mathrm{d}}(\lambda+\varepsilon / \mu) \cdot\left(\mathrm{dm}_{\mathrm{B}}\right) / \mathrm{dt}\right\} \\
\left(\mathrm{dm}_{\mathrm{B}}\right) / \mathrm{dt}=-\mathrm{f}_{\mathrm{w}}\left[\mathrm{T}(\mathrm{t}), \mathrm{W}_{\mathrm{c}}\right],
\end{gathered}
$$

Where:

$\mathrm{m}_{\mathrm{B}}$ - Is the mass of the body, $\mathrm{kg} ; \lambda=(2.503-2.255) 10^{6}$ Specific heat of free water evaporation, J.mol ${ }^{-1}$; $\varepsilon$ - adsorption potential; $\mu=0.018$ - vapor molar mass; $\mathrm{K}_{\mathrm{d}^{-}}$coefficient of proportionality.

The obtained differential equations cannot be integrated analytically and even numerical methods cannot be used. So we use different assumptions. To study the change in temperature we use the model (Lykov and Mikhailov, 1972)

$$
\Delta \mathrm{T}(\mathrm{t})=\mathrm{K}_{0}\left[1-\exp \left(-\mathrm{K}_{\mathrm{T}} \mathrm{t}\right)\right],
$$

Where:

We consider the empirical coefficients $\mathrm{k}_{0}$ and $\mathrm{k}_{1}$ as constants.

To identify the coefficients $\mathrm{k}_{0}$ and $\mathrm{k}_{1}$ we use the "linfit" function of the Mathcad-mathematical package (Makarov, 2011).

To study the change in humidity we see the model:

$$
\mathrm{U} / \mathrm{U}_{0}=(1-\mathrm{a} \cdot \Delta \mathrm{T})^{\mathrm{b} \cdot \mathrm{U}_{0}^{\mathrm{c}}}
$$

To identify the coefficients a, b, and c we use the "genfit" function of the Mathcad-mathematical package (Makarov, 2011).

\section{Statistical Analysis}

For statistical processing of the data obtained, we determined the mean root square deviation and the arithmetic-mean dispersion, at which point, we determined the mean root square deviation of the arithmetic mean. We conducted each experiment at least three times and determined the arithmetic mean of the computed value. We have obtained the value of the reliability coefficient which is $p<0.05$.

Statistical data are processed using the mathematical package- MathCad (Mathsoft, Cambridge, Massachusetts, USA), in particular, MathCad 15 (Makarov, 2011).

\section{RESULTS AND DISCUSSION}

The author (Lizenko et al., 1985; Ba et al., 2013) notes that starch undergoes hydrolysis on heating in presence of sulfuric acid, during which it produces glucose. Depending on the reaction conditions, hydrolysis can be carried out in successive phases, with the formation of intermediate products - dextrins.

(C6H10O5)n (starch) $\rightarrow$ (C6H10O5)m (dextrins $(\mathrm{m}<\mathrm{n}) \rightarrow$ $\mathrm{xC} 12 \mathrm{H} 22 \mathrm{O} 11$ (maltose) $\rightarrow$ nC6H12O6 (glucose)

Differential thermal analysis data obtained on a derivatograph show that starch has several endothermic peaks: $150^{\circ} \mathrm{C}$ and $225^{\circ} \mathrm{C}$, corresponding to amylose, and $140{ }^{\circ} \mathrm{C}$ and $275{ }^{\circ} \mathrm{C}$, corresponding to amylopectin (Lizenko et al., 1985). Exothermic peaks were observed at temperatures above $350{ }^{\circ} \mathrm{C}$.

To determine biochemical changes during the germination of rice grains and to increase the germination rate, the authors (Veluppillai et al., 2009) used gibberellic acid and surfactants (sodium dodecyl sulfate (SDS) (1.0 g.L ${ }^{-1}$ ) and Triton-X-100 (1.0 mL. $\left.\mathrm{L}^{-1}\right)$, whole rice grains soaked in distilled water for $12 \mathrm{~h}$ at $30^{\circ} \mathrm{C}$ were germinated in the dark at $30{ }^{\circ} \mathrm{C}$ for five days. The highest germination $(77.1 \%)$ was obtained on the 5th day. An increase in the content of

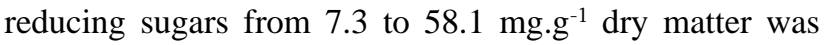
observed from the 1 st day of germination.

Complex carbohydrates undergo several transformations as a result of heating, which changes their structure and properties (Perez-Maldonado, 2002), and under the high heat impact (especially in the presence of a catalyst) can be split into relatively simple carbohydrates with a small molecular weight. During heating, the gelatinization process occurs, which is attributed to endothermic reactions with a specific heat capacity of $10-19 \mathrm{~kJ} \cdot \mathrm{kg}^{-1}$. The 
temperature range of gelatinization depends on the moisture content (Fast and Kolduell, 2007; Khosny, 2006). Our research agrees with this view.

With an increase in the irradiation and the time of IR heat treatment, the degree of gelatinization and the content of dextrins in the grain is increasing (Gunkin, 1992).

The study looked at some of the useful and available ingredients, making instant porridge. The data showed that the formula B2 which contained soaked mung beans, had the highest calorie content, total essential amino acids, biological value, and water absorption index (WAI). it was found that soaked mung beans were a good source of essential amino acids and calories to improve nutrition and the technological quality of the resulting porridge (Mahgoub, Mohammed and Mobarak, 2020).

In grain processing with infrared rays, activation of chemical processes occurs, which can substantially change its chemical composition and the influence of microorganisms (Deepa and Hebbar, 2016; Deepa and Hebbar, 2017).

The authors of (Teixeira et al., 2013) note that the seeds of some legumes (raw, steeped, or heated) came back with high levels of protein, which exceeds the levels found in other seeds of the same genus (from $16.8 \%$ to $29.3 \%$ ). The levels of protein $B$. cheilantha in the seeds are comparable or much higher than those indicated for some important cultivated legume seeds such as soybeans (from 39.5\% to $44.5 \%$ ) and cowpea (from $19.5 \%$ to $26.1 \%$ ). The seeds also found significant levels of dietary fibers, which were higher than those widely reported for the seeds of legumes such as soybeans (17.4\%) and black beans (22.6\%) (Trugo et al., 2000).

The authors (Klug et al., 2020) have developed an innovative cowpea puree has been developed, containing $78.8 \%$ fresh cowpea seeds. Microwave (8 kW/35 s), high hydrostatic pressure $\left(550 \mathrm{MPa} / 10 \mathrm{~min} / 23{ }^{\circ} \mathrm{C}\right.$ ) or sous-vide ( $80^{\circ} \mathrm{C}, 3 \mathrm{~min}$ ) were analyzed as treatment methods. However, the physicochemical properties, mainly the color, were greatly influenced by heat treatment, although the treatment under high hydrostatic pressure remained greenish.

The work is aimed at evaluating the ability of spelled wheat (Triticum aestivum spp. Spelta) to cook porridge compared to oats. The studied cereals are instant products based on extruded spelled or oat flour. The approximate composition, hydration properties (water absorption indexWAI and water solubility index-WSI), consistency, and thermal properties were determined to compare the characteristics of the porridge. In general, spelled porridge was higher in total and insoluble fiber, protein, minerals, and less available carbohydrates than oatmeal. (Šimurina et al., 2018).

The authors (Lund and Ray, 2017) take a critical look at recent advances in strategies for controlling the Maillard reaction and subsequent reaction products in food systems. Presents the main mechanisms involved, discusses the strengths and weaknesses of each strategy, and proposes reasonable response mechanisms to underpin the assessments. As a result, trapping or modification of Maillard targets, reactive intermediates, and glycation end products (AGEs) is manifested with their potential unwanted side effects.
The authors (Xu et al., 2020) note that there has been an increased interest in the application of Pulsed Electric Fields (PEF) technology as a pretreatment of plant-based foods before deep-frying to improve quality (e.g., lower browning tendency and oil uptake) and reduce production costs (e.g., better water and energy efficiencies). We have chosen high-temperature micronization for the pretreatment of legumes.

The authors (Jeong, Kim and Lee, 2020) investigated the effect of sequential pulsed electric field (PEF) processing, sous-vide cooking, and reheating on beef meat properties was investigated. Fresh meat was treated with PEF at various electric field strengths of 1.0, 1.5, and $2.0 \mathrm{kV} \cdot \mathrm{cm}^{-1}$, and then control beef samples and beef samples pretreated with PEF were cooked sous vide at $60{ }^{\circ} \mathrm{C}$ for up to $24 \mathrm{~h}$. PEF pretreatment resulted in fresh meat tenderizing in proportion to the increase in electric field strength.

After studying the grain quality and processing characteristics of durum wheat (Triticum turgidum subsp. Durum), heat stress during grain filling caused grain shrinkage with a decrease in weight and ultrastructural changes in the aleuron layer and in the endosperm cells, it is also suggested that, during grain filling, high temperatures may affect the strength of the gluten, reducing the quality of the wheat flour (Dias, Bagulho and Lidon, 2008).

The authors of (Vadivel, Nandety and Biesalski, 2011) note that some seeds of legumes are associated with the prevention of cardiovascular diseases, diabetes, and gastrointestinal diseases, given that they lower the glycemic index of food as well as cholesterol. The detected levels of moisture, ash, lipids, and digestible carbohydrates were lower or similar to those reported for legumes (Carvalho et al., 2011).

The authors (Sivakanthan et al., 2009) to determine biochemical changes used Gibberellic acid and surfactants (sodium dodecyl sulfate (SDS) (1.0 g.L ${ }^{-1}$ ) and Triton -X$\left.100\left(1.0 \mathrm{~mL} . \mathrm{L}^{-1}\right)\right)$, whole rice grains soaked in distilled water for 12 hours at $30{ }^{\circ} \mathrm{C}$, germinated in the dark at 30 ${ }^{\circ} \mathrm{C}$ for five days. The highest germination (77.1\%) was obtained on the 5th day. An increase in the content of

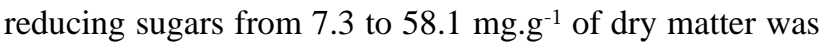
observed from the 1st day of germination. The content of free amino acids and soluble protein increased to 3.69 and $5.29 \mathrm{mg} \cdot \mathrm{g}^{-1} \mathrm{DM}$, respectively, on the $5^{\text {th }}$ day of germination.

The authors of (Kupkanchanakul et al., 2018) note the molecular weight distribution of pre-germinated brown rice starch (PGBRS) indicates partial hydrolysis of starch molecules, especially amylopectin, resulting in a decrease in the proportion of high molecular weight molecules after pre-germination.

The authors (Olaleye, Oresanya and Ogundipe, 2020) investigated the effect of fermentation time and temperature on the approximate composition and content of anti-nutrients in purified and unshelled Mucuna cochinchinensis flour. The results showed that fermentation time affected the approximate bean composition, causing a marked increase in crude protein (from 22.19 to $36.41 \%$ ) and fat (from 4.94 to $10.79 \%$ ) in the fermented bean samples. Mucuna. compared to the results of the 
unfermented samples (22.19 and 4.94\%), while the fermented beans showed a decrease in carbohydrates (from 57.34 to $40.85 \%)$.

This study showed that fermentation for $72 \mathrm{~h}$ at $45^{\circ} \mathrm{C}$ was most effective in increasing the nutritional value of the beans as well as reducing the antinutrient content to a minimum.

The authors in their articles do not mention foods such as starch and legume monosaccharides. In the view of many authors, they are the necessary products for the human body.

Standardization of data to $100 \mathrm{~g}$ samples of unpolished rice (dry matter basis), showed intra-varietal ranges of; $9 \mathrm{~g}$ protein, $5.65 \mathrm{mg}$ iron, $3.34 \mathrm{mg}$ zinc, $1.6 \mathrm{mg}$ thiamin, $0.392 \mathrm{mg}$ riboflavin, and $7.2 \mathrm{mg}$ niacin. Currently, several research institutions are working toward improving the nutrient content of rice (Kennedy and Burlingame, 2003).

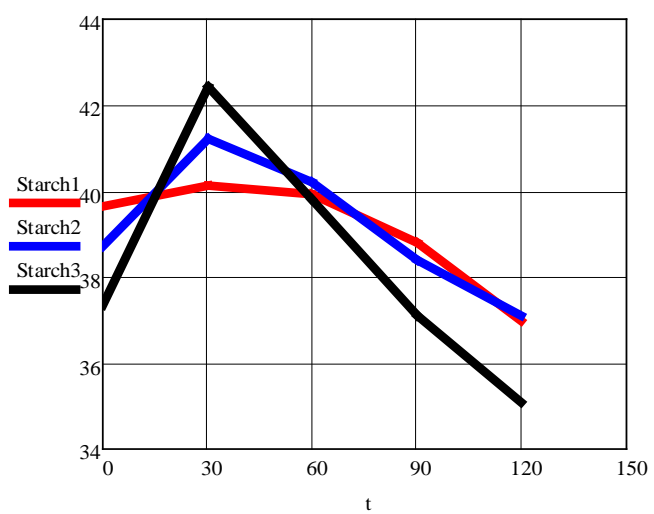

Figure 3 The dependence of the change in starch content on the length of exposure, „Tsanava“ bean variety. Note: The distance between the product and IR panel $\mathrm{H}=100 \mathrm{~mm}$; Moisture content: $1-\mathrm{W}_{0}=12.7 \% ; 2-\mathrm{W}_{0}=18.3 \% ; 3-\mathrm{W}_{0}=28.6 \%$. $\mathrm{t}:=(0,30,60,90,120)^{\mathrm{T}}, \operatorname{Starch} 1=(39.65,40.12,39.92,38.8,37.0)^{\mathrm{T}}, \operatorname{Starch} 2=(38.71,41.2,40.19,38.4,37.1)^{\mathrm{T}}, \operatorname{Starch} 3=$ $(37.36,42.42,39.8,37.1,35.08)^{\mathrm{T}}$.

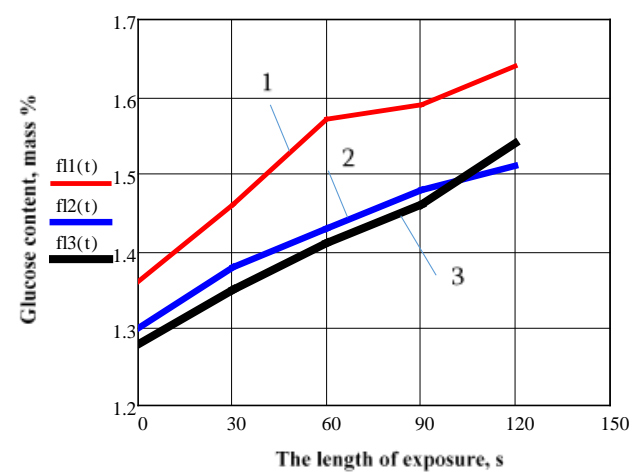

Figure 4 The dependence of the change in glucose content on the length of exposure, „Tsanava“ bean variety. Note: The distance between the product and IR panel $\mathrm{H}=100 \mathrm{~mm}$; Moisture content: $1-\mathrm{W}_{0}=12.7 \%$; $2-\mathrm{W}_{0}=18.3 \% ; 3-\mathrm{W}_{0}=28.6 \%$. $\mathrm{t}=(0,30,60,90,120)^{\mathrm{T}}$, Sugar $1=(1.36,1.46,1.57,1.59,1.64)^{\mathrm{T}}$, Sugar $2=(1.3,1.38,1.43,1.48,1.51)^{\mathrm{T}}$, Sugar $3=(1.28,1.35$, $1.41,1.46,1.54)^{\mathrm{T}}$.

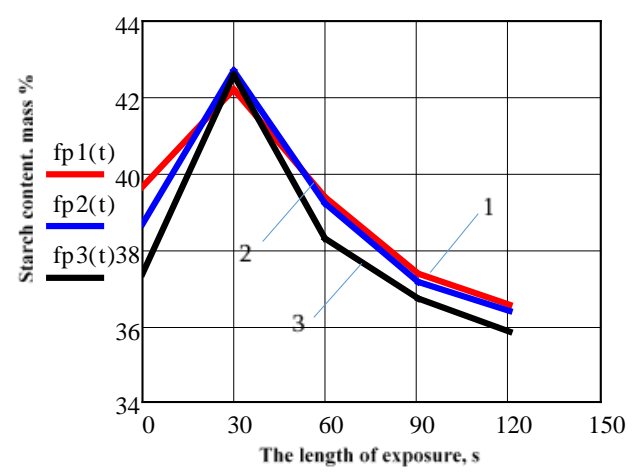

Figure 5 The dependence of the change in starch content on the length of exposure, „Tsanava“ bean variety. Note: The distance between the product and IR panel $\mathrm{H}=75 \mathrm{~mm}$; Moisture content: $1-\mathrm{W}_{0}=12.7 \% ; 2-\mathrm{W}_{0}=18.3 \% ; 3-\mathrm{W}_{0}=28.6 \%$. $\mathrm{t}:=(0$ $\left.\begin{array}{llll}30 & 60 & 90 & 120\end{array}\right)^{\mathrm{T}}, \quad$ Starch1 $:=\left(\begin{array}{llllll}39.63 & 42.18 & 39.4 & 37.35 & 36.53\end{array}\right)^{\mathrm{T}}, \quad$ Starch2 $:=\left(\begin{array}{lllll}38.7 & 42.7 & 39.21 & 37.14 & 36.4\end{array}\right)^{\mathrm{T}}$, Starch3 $:=\left(\begin{array}{lllll}37.38 & 42.6 & 38.92 & 36.72 & 35.86\end{array}\right)^{\mathrm{T}}$. 


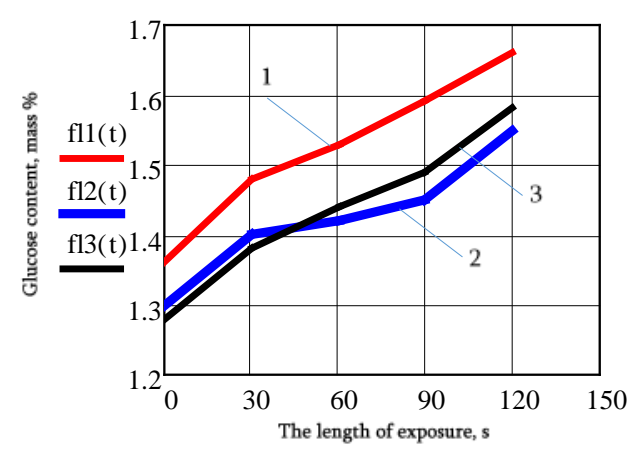

Figure 6 The dependence of the change in glucose content on the length of exposure, „Tsanava“ bean variety. Note: The distance between the product and IR panel $\mathrm{H}=75 \mathrm{~mm}$; Moisture content: $1-\mathrm{W}_{0}=12.7 \% ; 2-\mathrm{W}_{0}=18.3 \% ; 3-\mathrm{W}_{0}=28.6 \%$. $\mathrm{t}:=\left(\begin{array}{lllll}0 & 30 & 60 & 90 & 120\end{array}\right)^{\mathrm{T}}$, Sugar1 $:=\left(\begin{array}{llllll}1.36 & 1.48 & 1.53 & 1.59 & 1.66\end{array}\right)^{\mathrm{T}}$, Sugar2 $:=\left(\begin{array}{lllll}1.3 & 1.4 & 1.42 & 1.45 & 1.55\end{array}\right)^{\mathrm{T}}$, Sugar3 $:=$ $\left(\begin{array}{lllll}1.28 & 1.38 & 1.44 & 1.49 & 1.58\end{array}\right)^{\mathrm{T}}$.

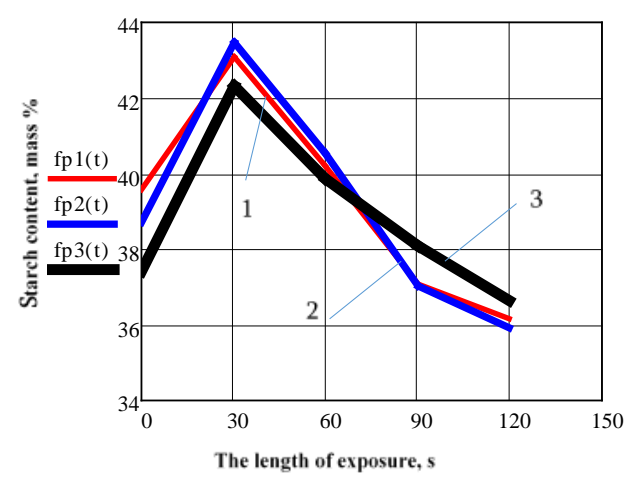

Figure 7 The dependence of the change in starch content on the length of exposure, „Tsanava“ bean variety. Note: The distance between the product and IR panel $\mathrm{H}=50 \mathrm{~mm}$; Moisture content: $1-\mathrm{W}_{0}=12.7 \%$; $2-\mathrm{W}_{0}=18.3 \%$; $3-\mathrm{W}_{0}=28.6 \%$. $\mathrm{t}:=\left(\begin{array}{lllll}0 & 30 & 60 & 90 & 120\end{array}\right)^{\mathrm{T}}$, Starch1 $:=\left(\begin{array}{llllll}39.6 & 43.1 & 40.2 & 37.1 & 36.14\end{array}\right)^{\mathrm{T}}$, Starch2 $:=\left(\begin{array}{lllll}38.71 & 43.45 & 40.54 & 37.04 & 39.94\end{array}\right)^{\mathrm{T}}$,

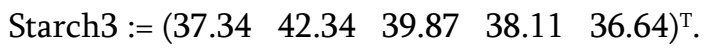

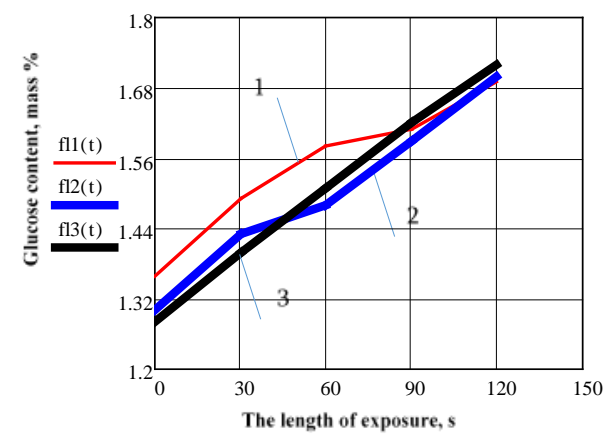

Figure 8 The dependence of the change in glucose content on the length of exposure, „Tsanava“ bean variety. Note: The distance between the product and IR panel $\mathrm{H}=50 \mathrm{~mm}$; Moisture content: $1-\mathrm{W}_{0}=12.7 \% ; 2-\mathrm{W}_{0}=18.3 \% ; 3-\mathrm{W}_{0}=28.6 \%$. $\mathrm{t}:=\left(\begin{array}{lllll}0 & 30 & 60 & 90 & 120\end{array}\right)^{\mathrm{T}}$, Sugar1 $:=\left(\begin{array}{lllll}1.36 & 1.49 & 1.58 & 1.61 & 1.69\end{array}\right)^{\mathrm{T}}$, Sugar2 $:=\left(\begin{array}{lllll}1.3 & 1.43 & 1.48 & 1.59 & 1.7\end{array}\right)^{\mathrm{T}}$, Sugar3 $:=\left(\begin{array}{ll}1.28\end{array}\right.$ $\left.\begin{array}{llll}1.4 & 1.51 & 1.62 & 1.76\end{array}\right)^{\mathrm{T}}$.

To increase the nutritional value and quickly prepare the legumes, we have chosen heat treatment with IR rays.

The authors (Iheke et al., 2017) studied the effect of fermentation on the physicochemical properties and nutrients of carob fruits. The approximate composition, mineral composition, anti-nutritional factors, and physicochemical properties of both unfermented and fermented samples were determined. The results showed

that fermented samples are better in nutritional value than unfermented seeds.

The authors (Skurikhin and Tutelyan, 2002) give the chemical composition of different varieties of beans without heat treatment, which is different from our data. After heat treatment, our data are approximated to their data.

The dependence of the change in starch content on the length of exposure during high-temperature micronization 
Table 2 Changes in starch content (mass \%) for the „field red“ bean variety with dependence on the duration of hightemperature micronization.

\begin{tabular}{|c|c|c|c|c|c|c|c|c|}
\hline \multirow[b]{2}{*}{ No } & \multirow[b]{2}{*}{$\begin{array}{c}\text { Initial moisture } \\
\text { content, } W_{0} \%\end{array}$} & \multirow[b]{2}{*}{ Biological parameter } & \multirow{2}{*}{$\begin{array}{c}\text { The distance } \\
\text { between the pro- } \\
\text { duct and IR } \\
\text { panel, mm }\end{array}$} & \multicolumn{5}{|c|}{ The length of exposure, $s$} \\
\hline & & & & $\mathbf{0}$ & 30 & 60 & 90 & 120 \\
\hline 1 & \multirow{2}{*}{17.5} & Starch, mass \% & \multirow{6}{*}{100} & 43.94 & 45.12 & 43.22 & 39.76 & 36.73 \\
\hline 2 & & Sugar, mass \% & & 1.05 & 1.28 & 1.41 & 1.63 & 1.95 \\
\hline 3 & \multirow{2}{*}{29.8} & Starch, mass \% & & 43.96 & 45.56 & 42.27 & 39.55 & 37.04 \\
\hline 4 & & Sugar, mass \% & & 1.01 & 1.22 & 1.68 & 1.97 & 2.12 \\
\hline 5 & \multirow{2}{*}{34.8} & Starch, mass \% & & 43.96 & 46.16 & 41.2 & 38.06 & 35.76 \\
\hline 6 & & Sugar, mass \% & & 0.95 & 1.55 & 2.0 & 2.36 & 2.54 \\
\hline 1 & \multirow{2}{*}{17.5} & Starch, mass \% & \multirow{6}{*}{75} & 43.94 & 45.42 & 43.63 & 39.16 & 35.93 \\
\hline 2 & & Sugar, mass \% & & 1.05 & 1.25 & 1.56 & 1.84 & 2.06 \\
\hline 3 & \multirow{2}{*}{29.8} & Starch, mass \% & & 43.96 & 45.87 & 43.44 & 38.78 & 36.23 \\
\hline 4 & & Sugar, mass \% & & 1.01 & 1.25 & 1.78 & 2.03 & 2.21 \\
\hline 5 & \multirow{2}{*}{34.8} & Starch, mass \% & & 43.96 & 46.02 & 41.82 & 37.86 & 35.14 \\
\hline 6 & & Sugar, mass \% & & 0.95 & 1.63 & 1.86 & 2.44 & 2.64 \\
\hline 1 & \multirow{2}{*}{17.5} & Starch, mass \% & \multirow{6}{*}{50} & 43.94 & 45.88 & 43.48 & 40.24 & 36.73 \\
\hline 2 & & Sugar, mass \% & & 1.05 & 1.28 & 1.64 & 1.95 & 2.07 \\
\hline 3 & \multirow{2}{*}{29.8} & Starch, mass \% & & 43.96 & 46.17 & 43.24 & 39.18 & 36.03 \\
\hline 4 & & Sugar, mass \% & & 1.01 & 1.31 & 1.85 & 2.1 & 2.3 \\
\hline 5 & \multirow{2}{*}{34.8} & Starch, mass \% & & 43.96 & 46.28 & 42.51 & 37.09 & 35.96 \\
\hline 6 & & Sugar, mass \% & & 0.95 & 1.72 & 1.93 & 2.52 & 2.73 \\
\hline
\end{tabular}

Table 3 Changes in starch content (mass \%) for the „white lupine“ variety with dependence on the duration of hightemperature micronization.

\begin{tabular}{|c|c|c|c|c|c|c|c|c|}
\hline \multirow{2}{*}{ No } & \multirow{2}{*}{$\begin{array}{l}\text { Initial moisture } \\
\text { content, } \mathrm{W}_{0} \%\end{array}$} & \multirow{2}{*}{$\begin{array}{l}\text { Biological } \\
\text { parameter }\end{array}$} & \multirow{2}{*}{$\begin{array}{l}\text { The distance bet- } \\
\text { ween the product } \\
\text { and IR panel, mm }\end{array}$} & \multicolumn{5}{|c|}{ The length of exposure, $s$} \\
\hline & & & & $\mathbf{0}$ & 30 & 60 & 90 & 120 \\
\hline 1 & \multirow{2}{*}{10.8} & Starch, mass \% & \multirow{6}{*}{100} & 40.65 & 44.4 & 42.7 & 41.7 & 40.5 \\
\hline 2 & & Sugar, mass \% & & 1.16 & 1.32 & 1.48 & 1.78 & 2.01 \\
\hline 3 & \multirow{2}{*}{20.5} & Starch, mass \% & & 40.66 & 45.4 & 41.43 & 40.63 & 40.14 \\
\hline 4 & & Sugar, mass \% & & 1.1 & 1.30 & 1.5 & 1.83 & 2.0 \\
\hline 5 & \multirow{2}{*}{26.8} & Starch, mass \% & & 40.66 & 45.67 & 41.2 & 39.84 & 39.1 \\
\hline 6 & & Sugar, mass \% & & 1.05 & 1.35 & 1.53 & 1.85 & 2.03 \\
\hline 1 & \multirow{2}{*}{10.8} & Starch, mass \% & \multirow{6}{*}{75} & 40.65 & 44.62 & 42.45 & 41.1 & 39.46 \\
\hline 2 & & Sugar, mass \% & & 1.16 & 1.38 & 1.63 & 1.88 & 2.07 \\
\hline 3 & \multirow{2}{*}{20.5} & Starch, mass \% & & 40.66 & 45.48 & 41.02 & 39.2 & 38.96 \\
\hline 4 & & Sugar, mass \% & & 1.1 & 1.38 & 1.62 & 1.92 & 2.1 \\
\hline 5 & \multirow{2}{*}{26.8} & Starch, mass \% & & 40.66 & 45.65 & 42.56 & 40.56 & 38.72 \\
\hline 6 & & Sugar, mass \% & & 1.05 & 1.47 & 1.75 & 1.96 & 2.19 \\
\hline 1 & \multirow{2}{*}{10.8} & Starch, mass \% & \multirow{6}{*}{50} & 40.65 & 45.56 & 42.2 & 40.6 & 38.64 \\
\hline 2 & & Sugar, mass \% & & 1.16 & 1.44 & 1.7 & 1.94 & 2.12 \\
\hline 3 & \multirow{2}{*}{20.5} & Starch, mass \% & & 40.66 & 45.67 & 40.76 & 39.1 & 38.2 \\
\hline 4 & & Sugar, mass \% & & 1.1 & 1.54 & 1.69 & 2.0 & 2.15 \\
\hline 5 & \multirow{2}{*}{26.8} & Starch, mass \% & & 40.66 & 45.8 & 40.78 & 38.28 & 37.68 \\
\hline 6 & & Sugar, mass \% & & 1.05 & 1.6 & 1.91 & 2.05 & 2.2 \\
\hline
\end{tabular}

at different distances between the product and IR panel for the "Tsanava" bean variety is shown in Figures 3, 5, and 7, while Figures 4, 6, and 8 illustrate the change in the glucose content.

Data on changes in starch content after high-temperature micronization for the "field red" bean variety are given in Table 2.

Data on changes in starch content after high-temperature micronization for the "white lupine" variety are given in Table 3.
As shown in Figure 2, the mass fraction of starch in the "Tsanava" beans increases at the initial stage of heat treatment, and then gradually decreases. The increase in the mass fraction of starch at the initial stage is more noticeable the higher the moisture content of the grain is. After 30 seconds of high-temperature micronization, at $12.7 \%$ moisture content of the grain, conditions of the starch content of the grain increases from $39.65 \%$ to $40.12 \%$, while at $18.3 \%$ moisture content, it increases from $38.71 \%$ to $41.2 \%$, and at $28.6 \%$ moisture content, it increases from $37.36 \%$ into $42.42 \%$. This must be because, at the initial 
stage of high-temperature micronization, moisture evaporation proceeds faster than the conversion of starch to dextrins and glucose.

This process is more pronounced when the infrared panel is less distant from the heat treatment surface, i.e. the higher the temperature in the heat treatment zone (Figures 5 and 7).

Similar processes are also observed for the beans "field red" (Table 2) and "white lupine" (Table 3), however, these processes are more intense when the geometrical dimensions of the grain are less (Tables 2 and 3), indicating that heat treatment takes place more intensively inside the grain.

As the mass fraction of starch decreases, the percentage of sugar increases slightly at the initial stage, in terms of the equivalent amount of glucose (Figure 3), and then the percentage of glucose increases relatively rapidly simultaneously with growth in the rate of starch deterioration. Similar processes take place in the case of "field red" bean (Table 2) and "white lupine“ (Table 3).

In this context, it should be noted that the study of the process of inactivation of alkaloids in legumes by the method of high-temperature micronization should be the subject of further research.

\section{CONCLUSION}

Our research and others have shown that the seeds of the studied legumes may be a promising alternative food source to overcome the malnutrition problem that people face. The legume seeds have a high protein content, an indispensable amino acid profile, and a low level of anti-nutritional compounds. When considering the composition of legumes, researchers focus on the content and importance of proteins in them, but also no less attention is paid to the content and importance of carbohydrates in legumes, which is less discussed in the scientific literature. It is noteworthy that in beans and white lupines, a sharp change in biological and chemical characteristics is possible as a result of hightemperature micronization. This method allows making full use of the nutritional potential of the studied legumes. It has been established that at this time, intensive partial hydrolysis of starch in legumes occurs, resulting in the formation of dextrins and glucose. We found that at the beginning of the high-temperature micronization of "Tsanava" beans at a grain moisture content of $12.7 \%$, the starch content in the grain increases from $39.65 \%$ to $40.12 \%$, then gradually decreases, and at a moisture content of $18.3 \%$ it increases from $38.71 \%$ to $41.2 \%$, with a humidity of $28.6 \%$, it increases from $37.36 \%$ to $42.42 \%$. Similar processes are observed for the „field red“ and “white lupine“ beans. This should be due to the fact that at the initial stage of high-temperature micronization, moisture evaporation occurs faster than the transformation of starch into dextrins and glucose, and naturally the mass fraction of starch grows, then, with the decomposition of starch, its mass fraction gradually decreases.

As the mass fraction of starch decreases, the percentage of sugar (in terms of the equivalent amount of glucose) at a moisture content of $12.7 \%$ initially increases from $1.36 \%$ to $1.46 \%$, and then the percentage of sugar increases relatively quickly to $1.64 \%$, at $18.3 \%$ humidity it increases from $1.3 \%$ to $1.38 \%$, then increases to 1.51 , at $28.6 \%$ humidity it increases from $1.28 \%$ to $1.35 \%$, and then increases to 1.54 .
Similar processes are observed for the "field red" and "white lupine" beans. The method of high-temperature micronization makes it easier to carry out the decomposition of starch into dextrins and glucose and the products obtained thereby are much more easily absorbed by the human body. At the same time, the considered legumes become easier to prepare, and their nutritional value increases.

\section{REFERENCES}

Afzal, M., Alghamdi, S. S., Migdadi, H. H., Khan, M. A., Mirza, S. B., El- Harty, E. 2020. Legume genomics and transcriptomics: From classic breeding to modern technologies. Saudi Journal of Biological Sciences, vol. 27, no. 1, p. 543-555. https://doi.org/10.1016/j.sjbs.2019.11.018

Ba, K., Aguedo, M., Tine, E., Paquot, M., Destain, J., Thonart, P. 2013. Hydrolysis of starches and flours by sorghum malt amylases for dextrins production. European Food Research and Technology, vol. 236, no.5, p. 905-918. https://doi.org/10.1007/s00217-013-1937-6.

Carvalho, A. F. U., Farias, D. F., Da Rocha-Bezerra, L. C. B., Sousa, N., Cavalheiro, M. G., Fernandes, G. S., Brasil, I. C. F., Maia, A. A. B., Sousa, D., Vasconcelos, I. M., Gouveia, S. T., Machado, O. 2011. Preliminary assessment of the nutritional composition of underexploited wild legumes from semi-arid Caatinga and moist forest environments of northe $\neg$ astern Brazil. Journal of Food Composition and Analysis, vol. $24 . \quad$ no. 4-5, p. 487-493. https://doi.org/10.1016/j.jfca.2011.01.013

Deepa, C., Hebbar, H. U. 2016. Effect of High-Tempera-ture Short-Time 'Micronization' of Grains on Product Quality and Cooking Characteristics. Food Engineering Reviews, vol. 8, no. 2, p. 201-213. https://doi.org/10.1007/s12393-015-9132-0

Deepa, C., Hebbar, H. U. 2017. Effect of micronization of maize grains on shelf-life of flour. Food processing and preservation, vol. 41, no. 5, p. 13-19. https://doi.org/10.1111/jfpp.13195

Dias, A. S., Bagulho, A. S., Lidon, F. C. 2008. Ultrastructure and biochemical traits of bread and durum wheat grains under heat stress. Brazilian Journal of Plant Physiology, vol. 20, no. 4, p. 553-566. https://doi.org/10.1590/S167704202008000400008

Fast, R., Kolduell, E. 2007. Khlopia na zavtrak (Breakfast cereals). Scientific foundations and technologies, St. Petersburg, Profession, vol. 528. (in Russian)

GOST 10845. 1998. Zerno I produkti ego pererabotki. Metod opredelenia krakhmala (Grain and products of its process $\neg$ sing. Method for determination of starch). Moskow, Interstate Council for Standardization, Metrology and Certification. (in Russian)

GOST 13586.5. 2015. Zerno. Metod opredelenia vlazhnosti (Grain. Moisture determination method (with amendments.) Moskow, Interstate Council for Standardization, Metrology and Certification. (in Russian)

GOST 29177. 2004. Zerno. Metodi opredelenia stepeni destrukcii krakhmala (Grain. Methods for determining the degree of starch destruction). Moskow, Interstate Council for Standardization, Metrology and Certification. (in Russian)

Gunkin, B. A. 1992. Optimizacia rezhimov IK obrabotki zerna rzhi po naboru biokhimicheskikh pokazatelei (Optimization of IR treatment modes for rye grain by a set of biochemical parameters) : dissertation theses. Moskow, MSUFI. (in Russian)

Iheke, E., Oshodi, A., Omoboye, A. J., Ogunlalu, O. 2017. Effect of Fermentation on the Physicochemical Pro-perties and 
Nutritionally Valuable Minerals of Locust Bean (Parkia biglobosa). American Journal of Food Technology, vol. 12, no. 6, p. 379-384. https://doi.org/10.3923/ajft.2017.379.384

ISO 1446. 2018. Green coffee - Determination of the moisture content - Basic reference method. Geneva: International Organization for Standardization.

ISO 3946. 1982. Starches and derived products Determination of total phosphorus content. Geneva: International Organization for Standardization.

ISO 6493. 2000. Animal feeding stuffs — Determination of starch content. Geneva: International Organization for Standardization.

ISO 3166. 2015. Codes for the representation of names of countries and their subdivisions - Part 1: Country codes (ISO 3166-1:2013)

Jeong, D., Han, J. A., Liu, Q., Chung, H. J. 2018. Effect of processing, storage, and modification on in vitro starch digestion characteristics of food legumes. A review. Food $\begin{array}{llll}\text { hydrocolloids, } & \text { vol. } & 90, & \text { p. }\end{array}$ 367-376. https://doi.org/10.1016/j.foodhyd.2018.12.039

Jeong, Se-Ho., Kim, E-Ch., Lee, D-Un. 2020. The Impact of a Consecutive Process of Pulsed Electric Field, Sous-Vide Cooking, and Reheating on the Properties of Beef Semitendinosus Muscle. Foods, vol. 9, no. 11, p. 1674. https://doi.org/10.3390/foods9111674

Kennedy, G., Burlingame, B. 2003. Analysis of food composition data on rice from a plant genetic resources perspective. Food Chemistry, vol. 80, no. 4, p. 589-596. https://doi.org/10.1016/S0308-8146(02)00507-1

Khosny, R. K. 2006. Zerno i zernovie produkti (Grain and grain products. Scientific foundations and technologies. St. Petersburg, Profession, 330 p. (in Russian)

Klug, T., Collado, E., Martínez-Sánchez, A., Gómez, P. 2020. Viability of sous vide, microwave and high pressure processing techniques on quality changes during shelf life of fresh cowpea puree. Food Science and Technology International, vol. 26, no. 8, p. 706-714. https://doi.org/10.1177/1082013220921059

Kupkanchanakul, W., Thongngam, M., Shi,Y.-Ch., Naivikul, O. 2018. Role of amylolytic activities during pregermi nation on rice kernel morphology and physicochemical pro- perties of isolated starch. Cereal Chemistry, Project: Rice and Rice starch, vol. 95, no. 4, p. 543-554. https://doi.org/10.1002/cche.10058

Lizenko, G. A., Bobrovnik, L. D., Nazarova, O. P. et al. 1985. Isledovanie modificirovannikh krakhmalov metodom derivatografa (Study of modified starches by the derivatograph method). Sugar industry, vol. 6. (in Russian)

Lund, M. N., Ray, C. 2017. Control of Maillard Reactions in Foods: Strategies and Chemical Mechanisms. Journal of Agricultural and Food Chemistry, vol. 65, no. 23, p. 45374552. https://doi.org/10.1021/acs.jafc.7b00882

Lykov, A. V., Mikhailov, Y. A. 1972. Theory of heat and mass-transfer. University of Michigan, USA : Israel Program for Scientific Translations publishers, 535 p. ISBN-10 0706505611 .

Mahgoub, S. A., Mohammed, A. T., Mobarak, El.-A. 2020. Physiochemical, Nutritional and Technological Properties of Instant Porridge Supplemented with Mung Bean. Food and Nutrition Sciences, vol. 11, no. 12, p. 1078-1095. https://doi.org/10.4236/fns.2020.1112076

Mainali, B. P., Kim, H. J., Yoon, Y. N., Oh, I. S., Do Bae, S. 2014. Evaluation of different leguminous seeds as food sources for the bean bug Riptortus pedestris. Journal of AsiaPacific Entomology, vol. 17, no. 2, p. 115-117. https://doi.org/10.1016/j.aspen.2013.11.007
Makarov, E. 2011. Enzhinernie raschoty v Mathcad 15 (Engineering Calculations in Mathcad 15). Moskow-St. Petersburg, Piter, 404 p. ISBN 978-5-459-00357-4. (in Russian)

Markov, P., Markov, D., Vodenicharova, A. 2016. Zdorovie i dieticheskie kharakteristiki zerna na osnove meditsinskikh dannikh (Healthy and dietary characteristics of grain on the basis of medical evidence). Science, Thought: electronic periodic e-journal, vol. 12, p. 24-29. (in Russian)

Moreno-Valdespino, C. A., Luna-Vital, D., Camacho-Ruiz, R. M., Mojica, L. 2019. Bioactive proteins and phytochemicals from legumes: mechanisms of action preventing obesity and type-2 diabetes. Food Research International, vol. 130, p. 108905. https://doi.org/10.1016/j.foodres.2019.108905

Murphy, K. J., Marques, L. I., Sánchez-Tainta, A. 2018. Cereals and legumes. In: Sánchez-Villegas, A., SánchezTainta, A. The prevention of cardiovascular disease through the Mediterranean diet. 1. Massachusetts : Elsevier, p. 111132. ISBN 9780128112595. https://doi.org/10.1016/B978-012-811259-5.00007-X

Ntatsi, G., Gutiérrez-Cortines, M. E., Karapanos, I., Barros, A., Weiss, J., Balliu, A., Savvas, D. 2018. The quality of leguminous vegetables as influenced by preharvest factors. Scientia Horticulturae, vol. 232, p. 191-205. https://doi.org/10.1016/j.scienta.2017.12.058

Olaleye, H., Oresanya, T., Ogundipe, O. O. 2020. Comparative study on proximate and antinutritional factors of dehulled and undehulled fermented Lyon bean (Mucuna cochinchinensis). Food Research, vol. 4, no. 5, p. 1611-1615. https://doi.org/10.26656/fr.2017.4(5).155

Perez-Maldonado, R. A., Mannion, P. F., Farell, D. J. 2002. Effects of heat treatment on the inhibitor activity. British Poultry Science, vol. 44, no. 2, p. 299-308. https://doi.org/10.1080/0007166031000085463

Recommendations for healthy. 2006. Recommendations for healthy nutrition for the population of Bulgaria. (18-65 let), MZ. S., 2006. 40 p.

Samchenko, O. 2014. Bobovie: Perspektivi ispolzovania dlia optimizatsii khimicheskogo sostava miasnikh polufabrikatov (Legumes: prospects of use for optimization of the chemical composition of semi-finished meat products). Science and modernity, vol. 28, p. 172-176. (in Russian)

Sivakanthan, S., Nithyanantharajah, K., Vasantharuba, S., Sandrasegarampillai, B. 2009. Biochemical Changes Associated with Germinating Rice Grains and Germination Improvement. Rice Science, vol. 16, no. 3, p. 240-242. https://doi.org/10.1016/S1672-6308(08)60085-2

Skurikhin, I. M., Tutelyan, V. A. 2002. Khimicheskii sostav russkikh pishevikh produktov (The chemical composition of Russian food products). Moskow, Russia : DeLi print, 236 p. ISBN 5-94343-028-8. (in Russian)

Šimurina, O. D., Filipčev, B. V., Marić, B. D., Cve-tković, B. R, Solarov, M. I. Bodroža. 2018. Comparative study on the physico-chemical, textural and thermal properties of instant porridges based on spelt and oats. Food and Feed Research, vol. 45, no. 1, p. 27-35. https://doi.org/10.5937/FFR1801027S

Teixeira, D. C., Farias, D. F., Urano Carvalho, A. F., Arantes, M. R., Oliveira, J. T. A., Sousa, D. O. B., Pereira, M. L., Oliveira, H. D., Andrade-Neto, M., Vasconcelos, I. M. 2013. Chemical Composition, Nutri-tive Value and Toxicological Evaluation of Bauhinia cheilantha Seeds. A Legume from Semiarid Regions Widely Used in Folk Medicine. Hindawi Publishing Corporation BioMed Research International, vol. 2013, p. 1-7. https://doi.org/10.1155/2013/578781

Tóth, T., Bystricka, J., Tomáš, J., Siekel, P., Kovarovič, J., Lenkova, M. 2018. Effect of sulphur fertilization on contents 
of phenolic and sulphuric compounds in onion (Allium cepa L.). Journal of Food \& Nutrition Research, vol. 57, no. 2, p.170-178.

Trugo, L. C., Donangelo, C. M., Trugo, N. M. F., Bach Knudsen, K. E. 2000. Effect of heat treatment on nutritional quality of germinated legume seeds. Journal of Agricultural and Food Chemistry, vol. 48, no. 6, p. 2082-2086. https://doi.org/10.1021/jf0256438

Vadivel, V., Nandety, A., Biesalski, H. K. 2011. Anti-oxidant potential and health relevant functionality of tra-ditionally processed Cassia hirsuta L. seeds: an Indian und- erutilized food legume. Plants Foods for Human Nutrition, vol. 66. p. 245-253. https://doi.org/10.1590/S1807-59322011000600026

Veluppillai, S., Nithyanantharajah, K., Vasantharuba, S., Balakumar, S., Arasaratnam, V. 2009. Biochemical Changes Associated with Germinating Rice Grains and Germination Improvement. Rice Science, vol. 16, no. 3, p. 240-242. https://doi.org/10.1016/S1672-6308(08)60085-2

Xu, Z., Leong, S. Y., Farid, M., Oey, I. 2020. Understanding the Frying Process of Plant-Based Foods Pretreated with Pulsed Electric Fields Using Frying Models. Foods, vol. 9, no. 7, p. 949. https://doi.org/10.3390/foods9070949

\section{Funds:}

This work was supported by Shota Rustaveli National Science Foundation of Georgia (SRNSFG) grant FR-198531 "Studying the Process of Obtaining Foods with Increased Nutrition Value from Some Leguminous Crops by Method of High-Temperature Micronization“.

\section{Conflict of Interest:}

The authors declare no conflict of interest.

\section{Ethical Statement:}

This article does not contain any studies that would require an ethical statement
Contact address

*Otari Sesikashvili, Akaki Tsereteli State University, Faculty of Engineering-Technical, Department of Mechanical engineering, Tamar - Mepe str. 59, 4600 Kutaisi, Georgia, Tel.: +995 5939662 42,

E-mail: otar.sesikashvili@atsu.edu.ge

ORCID: https://orcid.org/0000-0003-1229-4141

Elene Gamkrelidze, Akaki Tsereteli State University, Faculty of Engineering-Technological, Department of Chemical technology and Ecology, Tamar - Mepe str. 59, 4600 Kutaisi, Georgia, Tel.: +995 593 352781,

E-mail: elene.gamkrelidze@atsu.edu.ge

ORCID: https://orcid.org/0000-0002-0196-9505

Nodari Mardaleishvili, Akaki Tsereteli State University, Faculty of Engineering-Technical, Department of Mechanical engineering, Tamar - Mepe str. 59, 4600 Kutaisi, Georgia, Tel.: +995 558 368022,

E-mail: nodar.mardaleishvili@atsu.edu.ge ORCID: https://orcid.org/0000-0001-6785-2505

Gia Dadunashvili, Akaki Tsereteli State University, Faculty of Engineering-Technical, Department of Mechanical engineering, Tamar - Mepe str. 59, 4600 Kutaisi, Georgia, Tel.: +995 5773210 56,

E-mail: gia.dadunashvili@atsu.edu.ge

ORCID: https://orcid.org/0000-0001-8177-6430

Shalva Tsagareishvili, LTD „Kutaisi 2021“, Manager. 1 Lane, Nikea str. 4, 4600 Kutaisi, Georgia, Tel.: +995 59644 44 50,

E-mail: shakocagareishvili@mail.ru

ORCID: https://orcid.org/0000-0002-9347-6205

George Pkhakadze, San Diego State University, Department of Chemistry, Merab Kostava Str. 5, 0108, Tbilisi, Georgia.

E-mail: mariasilagadze@yahoo.com

ORCID: https://orcid.org/0000-0003-1179-2659

Corresponding author: * 